\title{
Campursari in Programing of Tvri East Java
}

\author{
Kukuh Sinduwiatmo ${ }^{1}$, Djarot Meidi Utomo \\ kukuh@umsida.ac.id
}

Universitas Muhammadiyah Sidoarjo

\begin{abstract}
The purpose of this study is to describe campursari in programming TVRI East Java. To reveal these objectives thoroughly and deeply, this study uses a qualitative descriptive method. While the data collection techniques used are interviews, observation and documentation. Then the data is analyzed critically on the basis of Morissan's theory (2011), so that the deep meaning of campursari in TVRI programming in East Java is obtained. From the results of this study found campursari in programming TVRI East Java in the form of planning where TVRI East Java made an idea before the campursari program aired and the selection of bumpers changed every year, the production strategy in which TVRI East Java had campursari programs which were self-produced and organize the technical crew as well as possible, evacuate the program where TVRI East Java shows the campursari program live in studio 1 TVRI. Each year evaluates the improvement of its program, especially on the screening of campurs so that it can later be accepted by the community.
\end{abstract}

Keywords: Campursari, Programming, Television Media.

\section{Introduction}

Mass media is a medium of information for the community. In the era of globalization the need for people to get information is increasing. Communities need communication tools that can be used at any time, especially electronic media that can immediately provide information quickly one of them television. Today television is a medium that is in demand by the public because television media has a strong connection with the audience.

One of the first local televisions in East Java was TVRI (Televisi Republik Indonesia), East Java, which was tasked with promoting government programs and holding a national consensus on national culture. As a public television, TVRI has the duty to provide information, education, entertainment, and preserve national culture as well as to present quality, educational and public programs [1]. This is in accordance with the vision and mission of TVRI itself.

TVRI provides a variety of programs, namely information, entertainment and education. TVRI. According to [2], the success of broadcast media is largely determined by the ability of its audience. Program strategies are reviewed from the management aspect or often also called the strategic management of broadcast programs which consist of: 1 . Program planning, 2. Program production and purchase, 3. Program execution, 4. Program monitoring and evaluation.

The presence of TVRI East Java which presents the campursari program was responded by various groups. To get a good quality program, programing is needed in order to 
attract audiences and can preserve campursari culture. Programming is an effort to create and improve the quality of programs so that they can get feedback from the community.

From these problems the researchers were interested in making the TVRI East Java Progaming Strategy in Preserving Campursari Culture as an object of research. As for the formulation of the problem in this study is What Is the Programming Strategy of East Java TVRI in Preserving Campursari Culture[3].

The purpose of this study was to determine the programming strategy of TVRI East Java in Preserving Campursari Culture.

\section{Methods}

This research uses descriptive qualitative method, the target in research is campursari in TVRI programming in East Java so far. This research was conducted at studio 1 of TVRI East Java, Jl.Mayjen Sungkono No. 124 Pakis Surabaya. Data collection techniques used in this study were observation, interviews and documentation. The collected data was analyzed by descriptive narrative

\section{Results}

\subsection{Programming}

Based on the theory of programming [4]. The form of program strategy according to includes:

\section{Program Planning}

Planning a television program is directed at being able to choose and schedule a program that can attract as many viewers as possible from the number of audiences at a given time.

\section{Program Production And Purchase}

Production of the campursari program starts at 18.00 WIB with live or live broadcast format. Before production begins, all performers, host and crew gather in the meeting room to listen to the direction of the program director. He also invited the host to read the outline of the things that must be done according to the theme given [5].

\section{Program Execution}

The program manager has determined a delivery schedule that is tailored to the plan and audience segment. Coordination with the promotion manager was also carried out to prepare promos for the program concerned. In structuring the program must be appropriate so that the desired results can be optimal [1].

The screening schedule is based on the behavior of the audience, because this is related to the airtime to be determined. In the campursari program, the broadcast time is taken at 
$18.00-19.00$, because at that time the audience or the community is at the hour while relaxing and with family [6].

\section{Program Monitoring and Evaluation.}

The preproduction process until post-production is done well so that it can produce the maximum program production. The program strategy carried out by TVRI East Java is starting from preproduction or planning is the theme selection. The second programing strategy is the selection of the campursari (casting) group, which is the event director and the producer comes directly to the campursari group practice site to conduct an audition. The third programming strategy is how to give a gimmick [7]. Gimmicks in the form of chatter or jokes from the host using Indonesian and Javanese Timuran languages to elevate the locality of these two languages [2].

\section{Conclusion}

The findings in this study indicate that the programing carried out by East Java TVRI in preserving campursari has gone through several steps, namely:

a. Program planning, the form of planning carried out by TVRI East Java in airing the campursari program was adjusted to pay attention to the audience segment and its vision and mission of participating to preserve culture [8]

b. The production and purchase of the program is carefully prepared. This was done by the event director as the person in charge of the event so that it was in accordance with the cooled results, especially the campursari program was the result of self-production by TVRI East Java.

c. The execution of the program by paying attention to showtime is an important part of the program that is broadcast, this is based on audience segmentation at the event. TVRI East Java shows the campursari program based on its behavior and segment audience.

d. Program monitoring and evaluation all the crew involved in the production of good theme selection programs, campursari players and program hosts were part of an intensive evaluation so that the event could run consistently with the hope that the program would be in demand by the community continuously [9].

Based on the results of this study, the authors have some suggestions as follows: campursari program programs should also be carried out offair in various regions. This is intended to bring closer together and introduce the community to campursari culture [10]. The event can also be packaged in the form of a campursari festival in an effort to find the potential that exists in the midst of society.

Acknowledgments. My gratitude goes to all the lecturers of the Faculty of Social and Political Sciences at the University of Muhammadiyah Sidoarjo who have provided opportunities and enthusiasm in writing this paper in the framework of the International Seminar (ICEMSS) that this work will bring benefits to its readers. 


\section{References}

[1] R. A. Syakur, "kompasiana,".

[2] M. A. Morisan, Broadcast Media Management 'Strategy for managing radio and televison,Jakarta:Kencana. Prenada Group.

[3] Koentjoroningrat, "Introduction to anthropology." Jakarta.

[4] Umar, Organizational Communication Research Methods. Jakarta: Gramedia.

[5] H. Nawawi, In the method of the field of social research, vol. (p. Yogyakarta: Gajah is a universal press.

[6] M. Q. D, "Mass Communication Theory." Salemba Jakarta.

[7] D. J. Priansa, Integrated Marketing Communication. Bandung loyal. library.

[8] M. Lj, Research Method. Gramedia Jakarta.

[9] T. Suprapto, "Introduction to Theory and Management of Communication," Medpress Yogjakarta.

[10] D. Mulyana, "Intrapersonal Communication. Bandung workshop.” . 